\title{
Epidemiology of the Spruce Budworm in Western Ontario: A Discussion
}

\author{
by
}

\author{
J.R. Blais ${ }^{1}$
}

\begin{abstract}
Spruce budworm outbreaks for the past two centuries in western Ontario occurred in two main sectors, the Lake Nipigon and the Lac Seul sectors. Some were common to both sectors, while others were specific to one or the other. Intervals between infestations within sectors averaged about 60 years. For western Ontario, budworm populations oscillated at irregular intervals ranging from 15 to 60 years. Infestations generally originated in the boreal forest in centers with high concentrations of fir, and then appeared in areas with lower volumes of fir. Fir content and the susceptibility to budworm attack of forests in western Ontario are compared with conditions prevailing in Quebec and the Maritimes. There are new outbreaks in western Ontario, and their future behavior could clarify some aspects of budworm epidemiology.
\end{abstract}

Key words: Spruce budworm, Choristoneura fumiferana; Balsam fir, Abies balsamea (L.) Mill.; Epidemiology.

\section{Résumé}

L'historique des épidémies de la tordeuse des bourgeons de l'épinette au cours des deux derniers siècles dans l'ouest de l'Ontario révèle que la plupart des épidémies ont eu lieu dans deux secteurs principaux, celui du Lac Nipigon et celui du Lac Seul. Certaines invasions ont affecté l'un ou l'autre de ces secteurs; dans d'autres cas les deux secteurs furent affectés simultanément. Dans un même secteur, les intervalles d'une invasion à l'autre furent longs avec une durée en moyenne de 60 ans. Pour l'ensemble de la région de l'ouest de l'Ontario, les populations de l'insecte ont fluctuées à des intervalles irréguliers variant de 15 à 60 ans. La plupart des épidémies ont débutées dans la forêt boréale à partir de centre à fortes concentrations de sapin et par la suite se sont répandues aux régions où les volumes en sapin étaient plus faibles. Le contenu en sapin et la susceptibilité aux attaques de la tordeuse des forêts de l'ouest de l'Ontario sont comparés aux conditions qui prévalent au Québec et dans les Maritimes. De nouvelles épidémies sévissent présentement dans l'ouest de l'Ontario. Le comportement de ces épidémies pourrait nous éclairer sur certains aspects de l'épidémiologie de la tordeuse.

Mots clés: Tordeuse des bourgeons de l'épinette, Choristoneura fumiferana; Sapin baumier, Abies balsamea (L.) Mill.; Epidémiologie.

\section{Introduction}

Outbreaks of the spruce budworm (Choristoneura fumiferana (Clem.)) occur periodically in eastern North America where balsam fir (Abies balsamea (L.) Mill.), white spruce (Picea glauca (Moench) Voss), and to a lesser extent, red spruce (Picea rubra Sarg.) predominate. The periodicity and behavior of outbreaks are affected by forest composition, climate, and man's actions. These factors vary in time and

1Laurentian Forestry Centre, Canadian Forestry Service, Sainte-Foy, Quebec G1V 4C7 place and this explains why the insect-forest relationship can differ between regions and between outbreaks within a region (Blais 1983). Observations conducted in a specific region during a particular infestation can lead to conclusions that do not apply to budworm outbreaks in general. Similarities and differences between regions and between outbreaks must be studied to understand the basic principles associated with the many facets of the ecology of the budworm. Between 1943 and 1954, I carried out investigations on several aspects of the spruce budworm problem in western Ontario during two separate but concurrent outbreaks, one near Lac Seul, the other in the Lake Nipigon sector (Fig. 1). After 1954, my studies 
on the budworm were conducted in several regions in Quebec and I also visited infestations in the Maritimes and Newfoundland. In the summer of 1983, I returned to western Ontario and toured areas where new budworm outbreaks were developing. The situation in western Ontario when compared with that in other regions, provides information that may lead to a better understanding of the epidemiology of the spruce budworm.

\section{History of Outbreaks in Western Ontario}

The history of budworm outbreaks prior to the 20th century in western Ontario was obtained through ring-growth studies on old-age white spruce trees (Blais 1954,1962, Elliott $1960)$. The only evidence of a budworm attack in the 18th century in this region was obtained by Turner ${ }^{2}$ in the Lake Nipigon area. It was based on radial-growth studies of a 300 year-old white spruce tree that showed a characteristic budworm suppresison pattern beginning in 1702 and lasting 10 years. Because no other host trees this old were found in western Ontario, the present discussion is based only on well documented evidence of outbreaks that occurred in the 19th and 20 th centuries.

Records from both the Lac Seul and Lake Nipigon sectors indicate that outbreaks began in both sectors about 1800 (Blais 1954, Elliott 1960). However, areas of origin and the limits of these outbreaks are unknown (Fig. 1). Another infestation began in the Lac Seul sector about 1862. This severe outbreak began near Sioux Lookout east of Lac Seul, it lasted about 12 years, and covered some $28000 \mathrm{~km}^{2}$ (Fig. 1). It affected the Lac Seul sector but not the Lake Nipigon sector (Blais 1954). Another outbreak began in the Lake Nipigon sector about 1880; it lasted 10 years and it was restricted to the area southwest of the lake (Elliott 1960) (Fig. 1)

The history of outbreaks in the 20th century is based on direct observations at the time they were taking place. The first of these outbreaks took place about 1925, it was confined to the Lac des Milles Lacs sector, $90 \mathrm{~km}$ west of Thunder Bay (Elliott 1960, Brown 1970) (Fig. 1). This light infestation was an extension of the series of severe infestations that affected northern Minnesota from 1912 to 1927 (Graham and Orr 1940). Budworm populations again reached outbreak levels in the Lac Seul and Lake Nipigon sectors about 1940 and were described in great detail by Elliott (1960). In the Lac Seul sector there were two areas of origin, one near Sioux Lookout and the other further west near Goldpines. The Lake Nipigon outbreak originated along the southwest shore of the lake (Fig. 1 ). Both outbreaks lasted several years, each eventually covered a very large area but they never joined (McGugan and Blais 1959, Elliott 1960, Brown 1970). They resulted in a loss of approximately 61 million $\mathrm{m}^{3}$ (17 million cords) of pulpwood. In both sectors, insect populations returned to endemic levels following food depletion.

Not until the late 1960s did budworm populations again show signs of being on the increase in western Ontario; defoliation occurred in several localities close to the international border (Kettela 1983). By 1977 there were two major areas of infestation, one near Fort Frances covering 146000 ha, the other covering 65000 ha $100 \mathrm{~km}$ to the east. (Howse et al. 1981) (Fig. 1). Another outbreak covering 60700 ha was detected in 1980, immediately southwest of Lake Nipigon (Howse et al. 1982). By 1983, the two infestation centers near

${ }^{2}$ K.B. Turner, Ontario Dept. of Lands and Forests, Forest Protection Branch, Toronto, Ontario, Canada. Personal Communication, February 5, 1965. the international border had joined and had spread to approximately 1.8 million ha. All fir-spruce stands from Fort Frances to about $50 \mathrm{~km}$ west of Thunder Bay, and stretching from the international border to the Trans-Canada highway were infested. In the Lake Nipigon sector, the area of infestation had also expanded and, in 1983, it covered 260000 ha (Fig. 1).

\section{History Lessons from Western Ontario Outbreaks}

Valuable information on budworm epidemiology can be gained from past and present budworm outbreaks in western Ontario. We know that budworm infestations have been recurring in this region for the past three centuries; probably they have been part of the dynamics of forests in western Ontario, as elsewhere in eastern North America, for much longer. Most of the recorded infestations were extensive, a few such as in 1880 and 1927 were restricted in area; the latter was the only detected outbreak of short duration.

Six outbreak periods have occurred during the past two centuries starting about 1800,1862,1880,1925, 1940, and 1967 (Fig. 1). The intervals between these successive outbreak periods are $62,18,45,15$, and 27 years indicating that in western Ontario detectable outbreaks have not oscillated at regular intervals.

Historical records reveal there are two main outbreak sectors in western Ontario, the Lac Seul and Lake Nipigon sectors. Since the beginning of the 19th century, the Lac Seul sector has been subjected to three outbreaks $(1800,1862$, and 1940) while the Lake Nipigon sector has been subjected to four $(1800,1880,1940$, and 1980). In the Lac Seul sector the time interval between succeeding infestations during the past two centuries has been 62 and 78 years; in the Lake Nipigon sector they have been 80,60 , and 40 years. When compared with other regions in eastern Canada, these intervals approach those recorded for the 19th century, but they are of much longer duration than elsewhere in the 20th century. The reasons for this appear to be the changes in the forest ecosystem resulting from man's actions which have increased balsam fir during the 20th century in most regions from central Ontario eastward; in western Ontario interventions by man are more recent and have affected the forest ecosystem over a shorter time (Blais 1983).

Balsam fir grows best in areas with a cool humid climate. This explains why this species, irrespective of changes in recent times resulting from human interventions, is more abundant in the east than in western Ontario where the climate is more continental. In several sectors in eastern Quebec and the Maritimes, fir comprises over $30 \%$ by volume of all tree species while in western Ontario, fir comprises less than $10 \%$ by volume of all tree species (Halliday and Brown 1943) (Fig. 2). Notwithstanding a low presence of fir, western Ontario has been subjected to periodic outbreaks of the spruce budworm, albeit at longer intervals than in the more eastern regions.

Because budworm infestations occur in western Ontario even though fir is relatively sparse in this region, it may be argued that fir is not as important a factor in the initiation of budworm outbreaks as has been supposed. Yet, a closer examination of the distribution of fir in western Ontario supports the premise that fir plays an important role in the epidemiology of the spruce budworm. According to Halliday and Brown (1943) there are two small areas with a high (11-30\%) concentration of fir, one immediately southwest of Lake Nipigon, the other at the eastern end of Lac Seul in the vicinity of 


\section{RECURRENCE OF SPRUCE BUDWORM OUTBREAKS DURING \\ THE PAST TWO CENTURIES IN WESTERN ONTARIO}
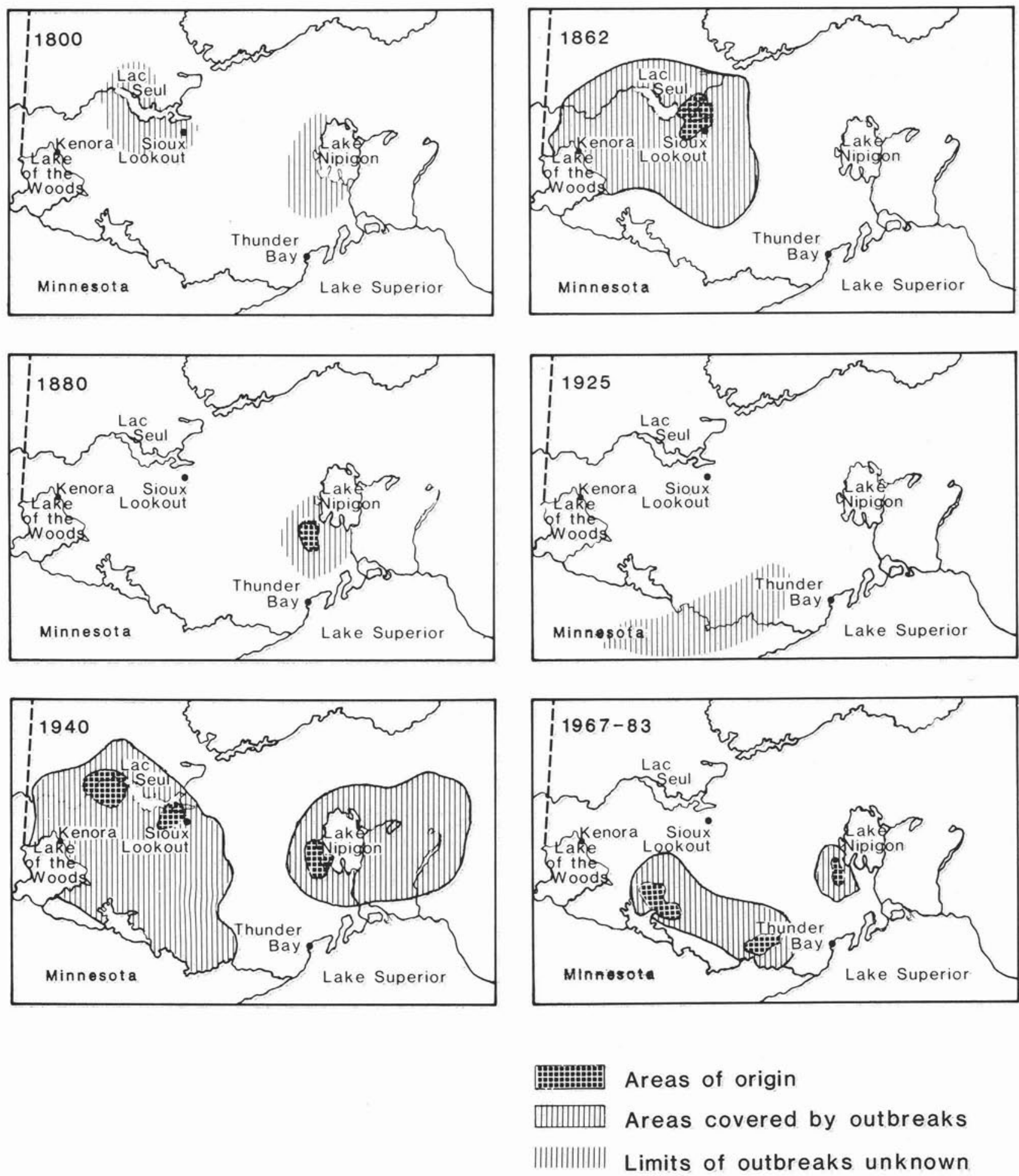

Figure 1. Areas affected by successive spruce budworm outbreaks that began about $1800,1862,1880,1925,1940$, and 1980 in western Ontario. The outbreaks that began about 1980 are still in progress; areas of infestation depict the situation in 1983 
Sioux Lookout (Fig. 2). It is significant that outbreaks in 1880 , 1940, and 1980 in the Lake Nipigon sector, and in 1862 and 1940 in the Lac Seul sector originated in one or the other of these areas of higher fir concentration (Fig. 1). A third area of high concentration of fir occurs in the vicinity of Burchell Lake where the recent outbreak began in 1967,3

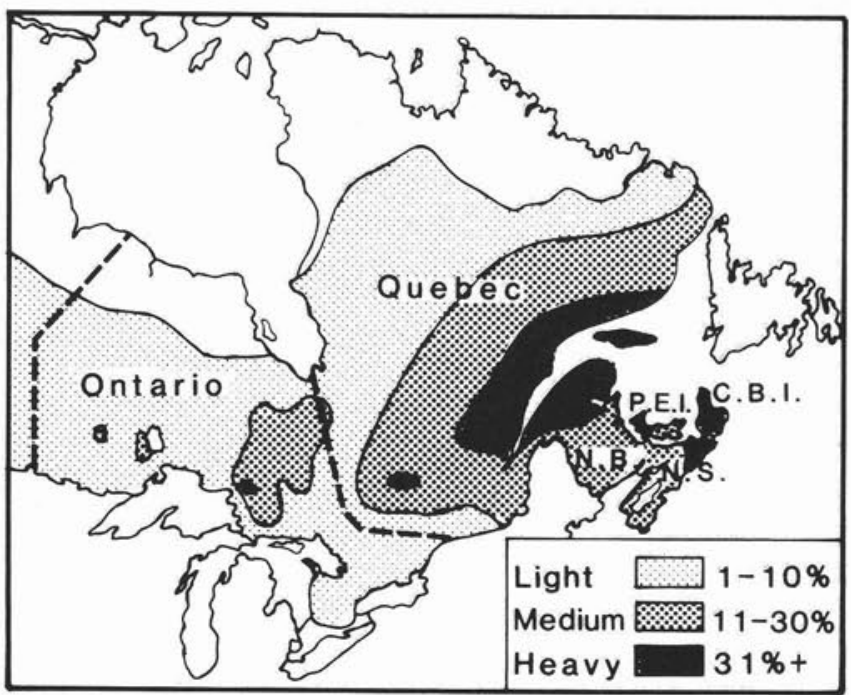

Figure 2. Population density of balsam fir in eastern Canada according to Halliday and Brown (1943).

Balsam fir and white spruce, the two main hosts of the budworm, are abundant in both the Great Lakes - St. Lawrence Forest Region and the southern sector of the Boreal Forest Region (Halliday and Brown 1943, Rowe 1972). Thus, outbreaks can originate in both regions. Recent studies conducted in Quebec have indicated that the latest budworm infestation in this province originated in several epicenters situated in mixed stands in the Great Lakes - St. Lawrence Forest Region, then spread to the Boreal Forest Region (Hardy 1979, Hardy et al. 1983). This led to the premise that this phenomenon was characteristic of the behavior of budworm outbreaks. The situation in western Ontario indicates that outbreaks can start in fir-spruce stands well within the Boreal Forest Region. The three last recorded outbreaks in the Lake Nipigon sector began in the Boreal Forest Region and remained confined to that region (Fig. 1). In the Lac Seul sector, the last two outbreaks also originated in the Boreal Forest Region, the first took 6 years (Blais 1954) and the second 12 years (Elliot 1960, Brown 1970) before spreading south to the Great Lakes - St. Lawrence Forest Region. In more recent years, a new outbreak began in 1967 in the southern sector of western Ontario and is spreading northward (Fig. 1). This indicates that in western Ontario outbreaks can originate either in the Great Lakes - St. Lawrence Forest Region or the Boreal Forest Region and from these spread to the adjoining region. Probably this phenomenon applies to most regions prone to budworm attack in eastern North America. Management measures to render the forest more resis- tant to budworm attack would have to be practiced broadly across regions where fir, white spruce, and to a lesser extent red spruce are abundant.

\section{The Current Situation}

During my 1983 tour of western Ontario, including the new outbreak centers in the Lake Nipigon and southern sector, I conducted observations along several roads remote from areas where moderate to severe defoliation prevailed. Whereever fir was present, examination of the foliage with binoculars revealed some light ( 1 to $5 \%$ ) budworm caused defoliation of the 1983 growth. Such defoliation was general as far as $60 \mathrm{~km}$ north of the main outbreak. At truly endemic levels, budworm density is so low that no defoliation can be detected (Blais 1959, Fye 1963, Miller and Renault 1976). The defoliation observed, although very light, indicates that populations had reached epidemic levels much beyond the delimited outbreak areas. It is not known whether this rise resulted from moth invasion originating from the main outbreak, or from increased survival in local populations.

Earlier studies in western Ontario (Blais 1952) and in New Brunswick (Greenbank 1963) have shown that staminate flowers on fir offer conditions favorable to larval survival. The presence of very large quantities of flower buds on the 1983 shoots indicate an extremely high production of flowers on balsam fir can be forecast for 1984 throughout the area visited. Moderate crops of flower are usually produced every second year on fir trees that are mature or approaching maturity. Occasionally, nearly all fir trees down to $5 \mathrm{~cm}$ dbh bear heavy crops. This generally takes place the year following a hot dry summer (Greenbank 1963), which applies in this instance since pronounced drought conditions prevailed in 1983 in western Ontario. The effect this could have on budworm populations in 1984 bears watching. The area of moderate to severe defoliation could increase considerably providing weather conditions unfavorable to the insect do not counteract the favorable conditions resulting from the presence of the flowers. ${ }^{4}$

Many fir stands where the outbreak began in 1967 close to the Ontario-Minnesota border have become mature. Although tree mortality occurred in this area during the 1940 outbreak, damage was not as severe as in the Lac Seul sector where mortality of mature and immature fir stands approached 100\% (Blais 1958, Elliott 1960). At that time firspruce stands were generally mature and overmature throughout the Lac Seul sector (Blais 1954). The killed stands were largely replaced by fir and spruce, and, at this stage, these young stands are between 30 and 40 years old. Should the current outbreak spread to the Lac Seul sector, it will be interesting to see whether insect populations will maintain epidemic levels in these relatively young stands. Hopefully, continued observations on the behavior of this outbreak will provide further information on the epidemiology of the budworm in western Ontario.

\section{Acknowledgments}

I wish to thank Dr. G.M. Howse for supplying maps of areas infested by spruce budworm in 1983 in western Ontario. 3Personal communication by G.M. Howse, Great Lakes Forestry Centre, Sault
Ste. Marie, Ont.
${ }_{4}^{4}$ The area of moderate to severe defoliation in western Ontario almost doubled in 1984; personal communication by G.M. Howse, Great Lakes Forestry Centre Sault Ste. Marie, Ont. 


\section{References}

Blais, J.R. 1952. The relationship of the spruce budworm (Choristoneura fumiferana (Clem.)) to the flowering condition of balsam fir (Abies balsamea (L.) Mill.). Can. J. Zool. 30: 1-29.

Blais, J.R. 1954. The recurrence of spruce budworm infestations in the past century in the Lac Seul area of northwestern Ontario. Ecology 35: 62-71

Blais, J.R. 1958. The vulnerability of balsam fir to spruce budworm attack in northern Ontario with special reference to the physiological age of the tree. For. Chron. 34: 405-422.

Blais, J.R. 1959. Incidence of overwintering parasites in postoutbreak populations of spruce budworm in Gaspé. Can. Dept. Agric. Div. For. Biol. Bi-mon. Prog. Rep.: (15) 6

Blais, J.R. 1962. Collection and analysis of radial growth data from trees for evidence of past spruce budworm outbreaks. For Chron. 38: 474-484

Blais, J.R. 1983. Trends in the frequency, extent, and severity of spruce budworm outbreaks in eastern Canada. Can. J. For. Res. 13: 539-547.

Brown, C.E. 1970. A cartographic representation of spruce budworm (Choristoneura fumiferana (Clem.)) infestation in eastern Canada, 1909-1966. Can. For. Serv. Rep. 1263

Elliott, K.R. 1960. A history of recent infestations of the spruce budworm in northwestern Ontario, and an estimate of resultant timber losses. For. Chron. 36: 61-82.

Fye, R.E. 1963. The status of the spruce budworm in the Black Sturgeon Lake Region of Ontario. Can. Dept. For., For. Ent. Path. Br., Bi-mon. Prog. Rep.: 19(2).

Graham, S.A. and L.W. Orr. 1940. The spruce budworm in Minnesota, Univ. Minn. Agric. Expt. Sta. Tech. Bul. 142.
Greenbank, D.O. 1963. Staminate flowers and the spruce bud worm In R.F. Morris, ed. The dynamics of epidemic spruce budworm populations. Mem. Ent. Soc. Can. 31, p. 174-180.

Halliday, W.E. and A.W.A. Brown. 1943. The distribution pattern of some important trees in Canada. Ecology 24: 353-373.

Hardy, Y.J. 1979. Les recherches sur la tordeuse des bourgeons de l'épinette. Revue forestière française 31: 217-223.

Hardy, Y.J., A. Lafond and A. Hamel. 1983. Epidemiology of the current spruce budworm outbreak in Quebec. For. Sci. 29 715-725.

Howse, G.M., H.L. Gross and A.H. Rose. 1981. In Annual Report, Forest Insect and Disease Survey 1977. Environ. Can., For Serv. Ottawa, Ont., p. 51-69.

Howse, G.M., A.A. Harnden, J.H. Meating and J.R. Carrow. 1982. The 1980 spruce budworm situation in Ontario. Environ. Can. For. Serv., Great Lakes For. Res. Centre, Sault Ste. Marie. Inf Rep. 0-X-343. $92 \mathrm{p}$

Kettela, E.G. 1983. A cartographic history of spruce budworm defoliation 1967 to 1981 in eastern North America. Can. For. Serv. Inf. Rep. DPC-X-14. Ottawa, Ont.

McGugan, B.M. and J.R. Blais. 1959. Spruce budworm parasite studies in northwestern Ontario. Can. Ent. 91: 758-783.

Miller, C.A. and T.R. Renault. 1976. Incidence of parasitoids attacking spruce budworm populations in New Brunswick. Can. Ent. 108: 1045-1052.

Rowe, J.S. 1972. Forest regions of Canada. Can. Dep. Environ., Can For. Serv. Publ. 1300

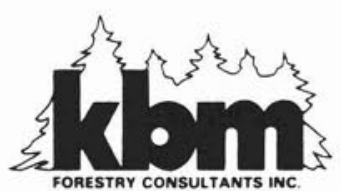

360 mooney street

thunder bay, ontario

P7B 5R4

REFORESTATION EQUIPMENT

- Sales Service Parts Repair

REGENERATION \& SITE PREPARATION

- Contract Assessment Consulting

807-344-0811 telex 073-4603 